\title{
Hanford Site Anuran Monitoring Report for Calendar Year 2013
}

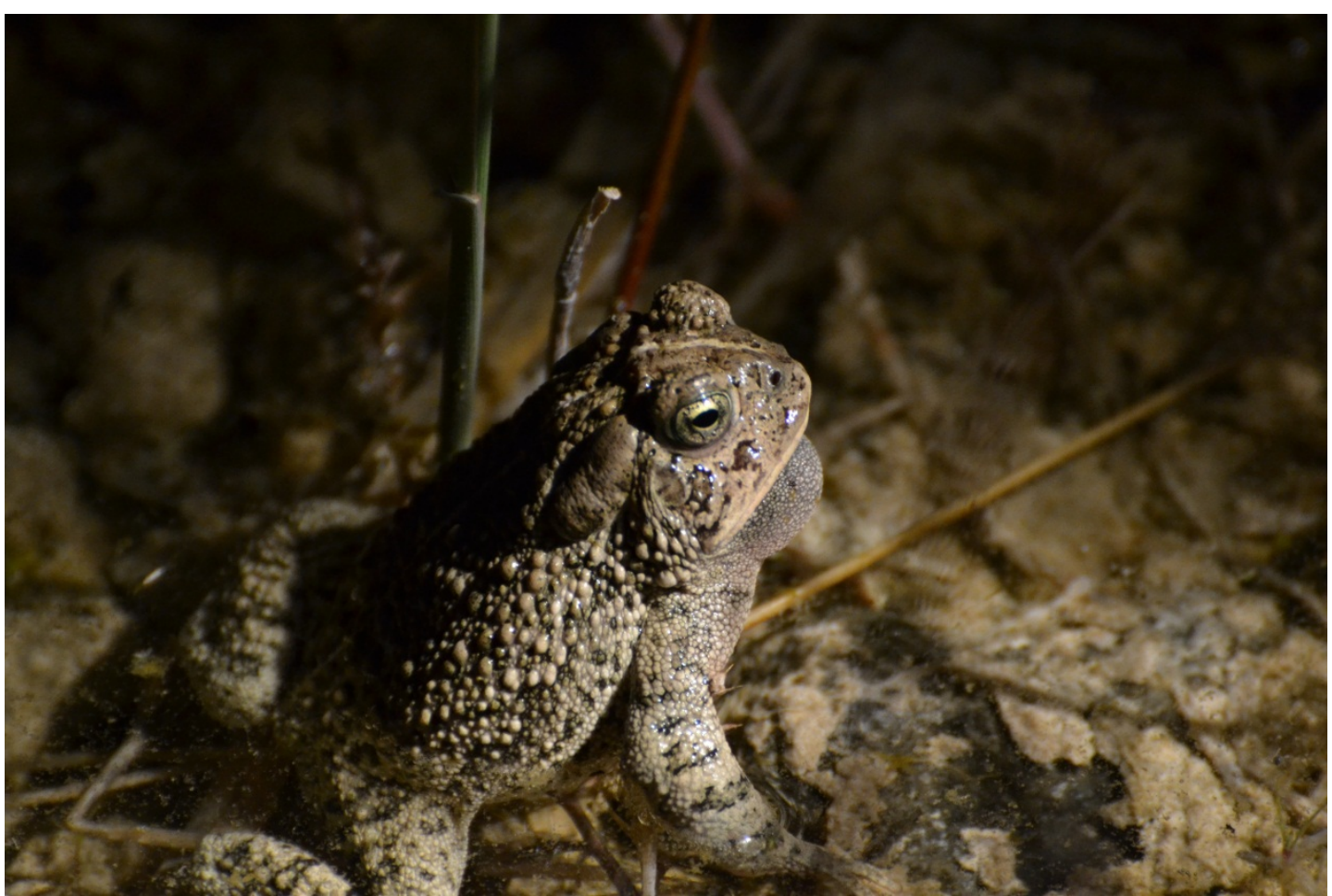

Prepared for the U.S. Department of Energy

Assistant Secretary for Environmental Management

Contractor for the U.S. Department of Energy

under Contract DE-AC06-09RL14728

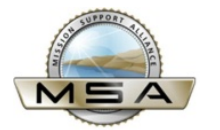

P.O. Box 650

Richland, Washington 99352 
HNF-56676

Revision 0

TRADEMARK DISCLAIMER

Reference herein to any specific commercial product, process, or service by trade name, trademark, manufacturer, or otherwise, does not necessarily constitute or imply its endorsement, recommendation, or favoring by the United States Government or any agency thereof or its contractors or subcontractors.

This report has been reproduced from the best available copy.

Printed in the United States of America

The cover photo is courtesy of Justin Wilde. 


\section{Hanford Site Anuran Monitoring Report for Calendar Year 2013}

J.W. Wilde, S.J. Johnson and C.T. Lindsey Mission Support Alliance

Date Published

February 2014

Prepared for the U.S. Department of Energy

Assistant Secretary for Environmental Management

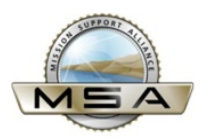

P.O. Box 650

Richland, Washington 99352

By Janis D. Aardal at 11:43 am, Feb 13, 2014

Release Approval

Date 


\section{Contents}

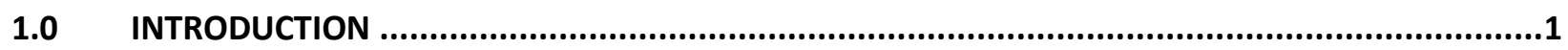

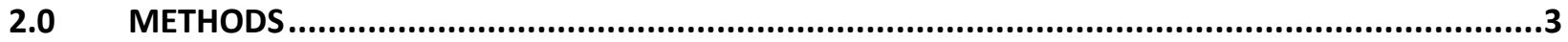

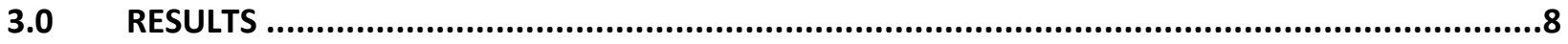

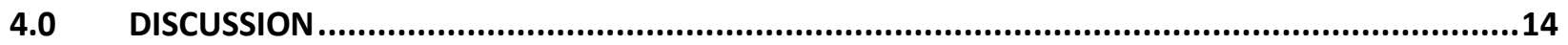

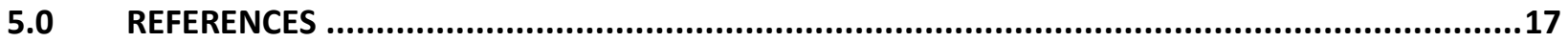

Figures

Figure 1. Fifteen Potential Anuran Breeding Pool Sites Previously Identified on the Hanford Site ............ 4

Figure 2. Field Camera Recording Surface Level Fluctuations at Pool 9 on the Hanford Site ................... 7

Figure 3. Anuran Pools Surveyed on the Hanford Site in 2013 ........................................................... 8

Figure 4. Average Hourly Flows and Isolation Periods of Four Riverine Pools for Potential Anuran Breeding

Figure 5. Anuran Breeding Pools on the Hanford Site with Sufficient Time for Breeding to Occur by End of August 2013

Figure 6. Outflow at Priest Rapids Dam During 2013 Compared to a High, Low, and 10 Year Average Outflow (CRDART 2013)

\section{Tables}

Table 1. Anuran Site Names, Locations, and Type on the Hanford Site ............................................... 5

Table 2. Flow Levels Identified when Each Pool is Isolated and Filled.................................................... 6

Table 3. Individuals Documented by Species during Chorus Surveys, 2013 ...........................................9

Table 4. Pool Site Isolation Times on the Hanford Site during the Breeding Season ............................... 12 
HNF-56676

Revision 0

\subsection{Introduction}

The U.S. Department of Energy, Richland Operations Office (DOE-RL) conducts ecological monitoring on the Hanford Site to collect and track data needed to ensure compliance with an array of environmental laws, regulations, and policies governing DOE activities. Ecological monitoring data provide baseline information about the plants, animals, and habitat under DOE-RL stewardship at Hanford required for decision-making under the National Environmental Policy Act (NEPA) and Comprehensive Environmental Response, Compensation, and Liability Act (CERCLA). The Hanford Site Comprehensive Land Use Plan (CLUP, DOE/EIS-0222-F) which is the Environmental Impact Statement for Hanford Site activities, helps ensure that DOE-RL, its contractors, and other entities conducting activities on the Hanford Site are in compliance with NEPA.

The Hanford Site Biological Resources Management Plan (BRMP, DOE/RL 96-32 Rev 1) is identified by the CLUP as the primary implementation control for managing and protecting natural resources on the Hanford Site. According to the CLUP, the BRMP

"provides a mechanism for ensuring compliance with laws protecting biological resources; provides a framework for ensuring that appropriate biological resource goals, objectives, and tools are in place to make DOE an effective steward of the Hanford biological resources; and implements an ecosystem management approach for biological resources on the Site. The BRMP provides a comprehensive direction that specifies DOE biological resource policies, goals, and objectives."

DOE-RL places priority on monitoring those plant and animal species or habitats with specific regulatory protections or requirements; or that are rare and/or declining (federal or state listed endangered, threatened, or sensitive species); or of significant interest to federal, state, or tribal governments or the public. The BRMP ranks wildlife species and habitats (Levels 0-5), providing a graded approach to monitoring biological resources based on the level of concern for each resource. Ephemeral streams and vernal pool areas are ranked as Level 5 resources, the highest ranking level in BRMP. Anurans use these streams and pools as their preferred breeding habit along the Hanford Reach. The Woodhouse's toad (Anaxyrus woodhousii) is a Washington State Monitor species, a level 2 resource. The combination of resource levels provide a basis for monitoring of the anurans, including Woodhouse's toad, on the Hanford Site.

The order Anura, within the class Amphibia, includes the frogs and toads (Campbell and Reece 2002). Monitoring of the anuran populations is an important piece of the comprehensive ecological monitoring of the Hanford Site. This importance is heightened with the outbreak of chytridiomycosis in anuran populations around the globe. This disease, caused by the chytrid fungus (Batrachochytrium dendrobatidis), is implicated in the widespread decline of anurans. The fungus and disease has been documented within the Columbia Basin (Hayes et al. 2009). This disease has caused many species to be listed as threatened or endangered, and continued monitoring of populations on the Hanford Site is 
necessary to ensure that these populations continue to exist. Monitoring documents the locations and relative abundance of sensitive species and their habitats. This information can then be used to help protect the species from adverse impacts and to determine if any significant population or distribution changes should be investigated.

Three species of anurans are documented on the Hanford Site: two native species, the Woodhouse's toad (a Washington State Monitor species [WDFW 2013]) and the Great Basin spadefoot toad (Spea intermontana), and one introduced species the American bullfrog (Lithobates catesbeianus). Other anurans that have been recorded on the Hanford Site are the Western toad (Anaxyrus boreas) and Pacific chorus frog (Pseudacris regilla) (TNC 1999), although more recent work have not documented these species (Becker and Miller 2005, Miller 2010). Historical populations of Northern leopard frog (Lithobates pipiens), a Washington Department of Fish and Wildlife (WDFW) state endangered species, have been documented nearby in Benton County and populations are currently documented in tributaries of the Columbia River to the north of the Hanford Site (McAllister 1999). The anurans on the Hanford Site live and breed in the ephemeral pools and sloughs adjacent to the Columbia River.

The Hanford Reach is a free-flowing (unimpounded) section of the Columbia River that provides a natural boundary along the northern and eastern sections of the DOE-RL managed portion of the Hanford Site (Burk et al. 2007). Although the portion of the Columbia River along the Hanford Reach is unimpounded, it is heavily influenced by upstream hydroelectric power facilities, which directly influence river conditions such as discharge levels. Anurans are dependent on the pools and sloughs that are created along the shorelines of the Hanford Reach when the river level fluctuates (Miller 2010).

In 2003, 15 ephemeral pools, and river bank / backwater slough sites were identified as potential anuran breeding habitats by Pacific Northwest National Laboratory (PNNL) (Becker 2011). Anuran population characteristics/habitat-use data have not been collected on the Hanford Site since 2008. Since the transition of the Public Safety and Resource Protection (PSRP) program to Mission Support Alliance (MSA) in 2011, current breeding status of these sites is unknown. The presence or absence of suitable habitat at these sites is dependent on river level fluctuations and monitoring these areas provides a better understanding of the breeding success and population distribution of anurans on the Hanford Site (Miller 2004). Loss of these habitats would ultimately be detrimental to their survival. Hanford Site anurans are sentinel species and serve as fundamental indicators of ecological health, and as receptor species in ecological assessments (Becker and Miller 2005). Anuran monitoring provides a status of the riparian ecosystem on the Hanford Site and documents valuable ecological resources for protection and information for effective natural resource management. 
HNF-56676

Revision 0

\subsection{Methods}

The Hanford Reach represents a unique opportunity as a study site. Its location within the Hanford Site allows for the shorelines to remain largely undeveloped, while much of the surrounding area has been transformed into agriculture, residential or commercial development. The largely undisturbed shoreline serves as a refuge for plants and wildlife. In an unregulated riverine system, spring freshets followed by lower summer flows would create ephemeral pools along the shorelines that could be used by anurans for breeding. While the Columbia River is free from dam impoundment along the Hanford Site, water flows are regulated by releases at upriver dams. Therefore, flow fluctuations from upstream dam activity create ephemeral pools along the shoreline of the Hanford Reach. In 2003, WDFW performed aerial flights identifying isolated pools in a project to identify salmon stranding pools (WDFW 2003). PNNL reviewed the aerial footage from those WDFW flights and determined fifteen pools with potential to be amphibian breeding pools (Becker 2011). The fifteen pools were monitored for anuran activity in multiple years through 2008. The fifteen pools located across the river corridor are shown in Figure 1. Table 1 describes each pool's location and flow type. 
HNF-56676

Revision 0

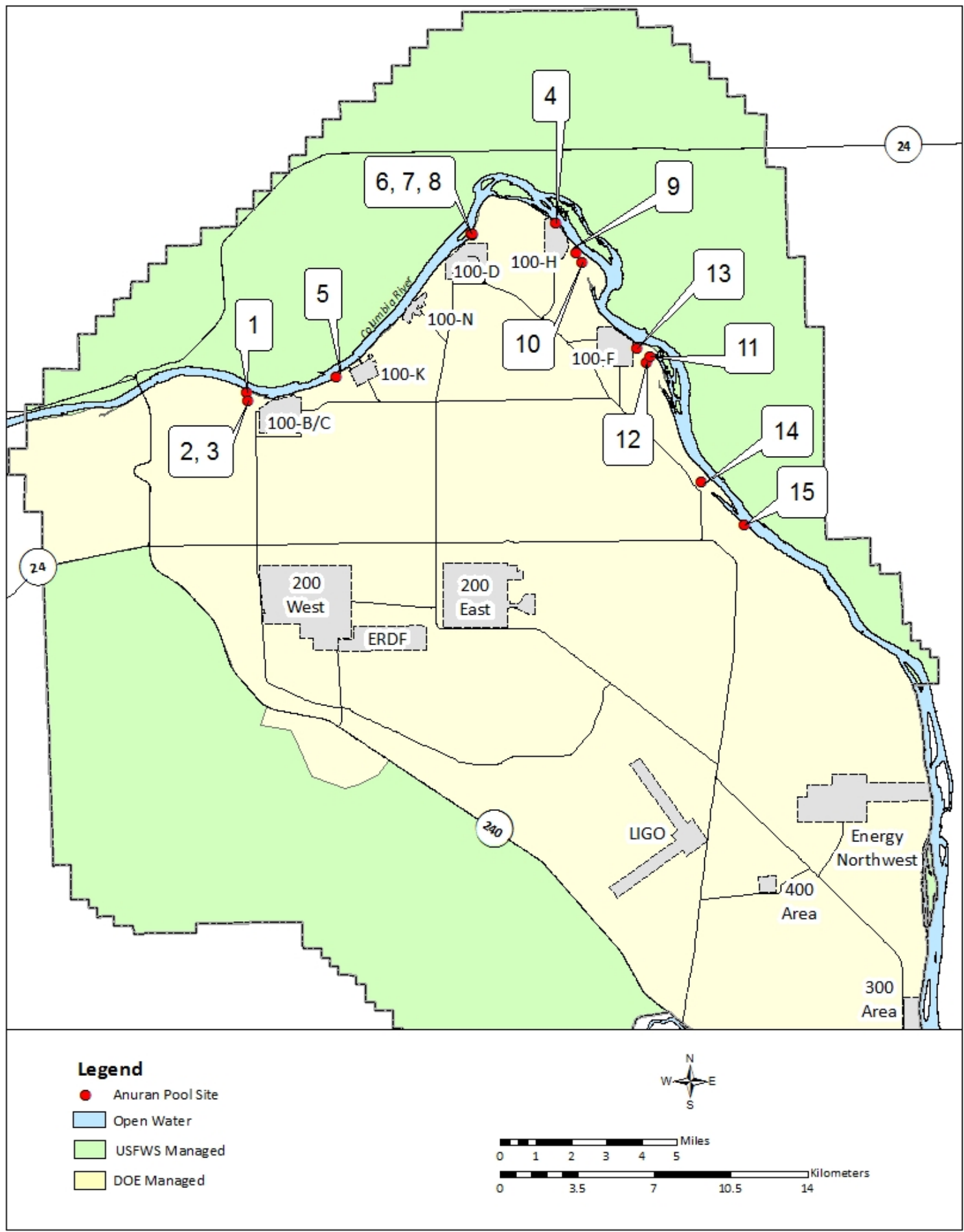

Figure 1. Fifteen Potential Anuran Breeding Pool Sites Previously Identified on the Hanford Site 
Table 1. Anuran Site Names, Locations, and Type on the Hanford Site

\begin{tabular}{llr} 
Site Name & General Location & Site Type \\
\hline Pool 1 & Adjacent to 100-B/C & Pool \\
Pool 2/3 & Borrow Pit 24 & Pool \\
Pool 4 & Upstream of 100-H & Slough \\
Pool 5 & Adjacent to Coyote Rapids & Slough \\
Pool 6 & Downstream of 100-D & Slough/pool \\
Pool 7 & Downstream of 100-D & Slough/pool \\
Pool 8 & Downstream of 100-D & Slough/pool \\
Pool 9 & Downstream of 100-H and upstream of 100-H Slough & Pool \\
Pool 10 & Downstream of 100-H and upstream of 100-H Slough & Pool \\
Pool 11 & 100-F Slough & Pool \\
Pool 12 & 100-F Slough & Pool \\
Pool 13 & 100-F Slough & Pool \\
Pool 14 & Upstream of the Hanford Townsite Slough & Pool \\
Pool 15 & Adjacent to Hanford Townsite & Pool
\end{tabular}

The creation of a suitable breeding pool, combined with warm weather nights, triggers breeding on the Hanford Reach. These pool creation events can be due to river level fluctuation or heavy rainfall. In a naturally regulated system, these pool creation events typically occur a small number of times or only once during a breeding season. The controlled water releases from the dams upriver of the Hanford Reach can cause flow fluctuations within a 24-hour period of up to four meters and over two meters in a single hour (Anglin et al. 2006). These flow fluctuations can cause a high number of inundations at a given pool within a breeding season, often occurring daily. Documenting these fluctuations over an anuran breeding season was determined to be useful for assessing the viability of the fifteen identified pools on the Hanford Reach.

Flow data were gathered from the U.S. Geological Survey (USGS) National Water Information System for station "USGS 12472800 Columbia River below Priest Rapids Dam, WA" (USGS 2013). These data were compared to existing shoreline maps with $10 \mathrm{kcfs}$ flow band intervals to determine the flow level at which each pool was filled or isolated. Each of the 15 pools was given a "filled" or "isolated" flow level, as shown in Table 2. Because attenuation of low fluctuations increases with greater distance from the upstream dam, pools were only considered filled or isolated if flows exceeded the respective trigger level for four hours. An individual pool was initially created when it was first inundated by flows greater than the "filled" level, then isolated from the main river channel by flows lower than the "isolated" level. That pool was then considered a viable breeding habitat until it was inundated again by increasing flows. For the purposes of this project, the clock was reset for pool viability if an individual pool was reinundated. Pools were considered reset due to the changes in temperature and flow associated with inundation and to the potential for any eggs or tadpoles to be swept out of the pool into the main river channel. Larval development (hatching to the emergence of the first forelimb) is completed in about 47 days in spadefoot toad and about 56 days in Woodhouse's Toad (Lannoo 2005). A viable breeding 
pool would need to be filled and isolated for approximately 50 days for complete larval development to occur.

\section{Table 2. Flow Levels Identified when Each Pool is Isolated and Filled}

$\begin{array}{ccc}\text { Pool Number } & \text { Inundation (kcfs) } & \text { Isolation (kcfs) } \\ \mathbf{1} & 140 & 110 \\ \mathbf{2} & \text { Borrow Pit (N/A) } & \text { Borrow Pit (N/A) } \\ \mathbf{3} & \text { Borrow Pit (N/A) } & \text { Borrow Pit (N/A) } \\ \mathbf{4} & 150 & 120 \\ \mathbf{5} & 160 & 130 \\ \mathbf{6} & 130 & 90 \\ \mathbf{7} & 110 & 85 \\ \mathbf{8} & 110 & 100 \\ \mathbf{9} & 190 & 160 \\ \mathbf{1 0} & 190 & 160 \\ \mathbf{1 1} & 160 & 140 \\ \mathbf{1 2} & 170 & 120 \\ \mathbf{1 3} & 210 & 200 \\ \mathbf{1 4} & 190 & 180 \\ \mathbf{1 5} & 150 & 90\end{array}$

Vocalization, termed chorusing, is an important breeding behavior of most anuran species, and is species-specific, making each species distinguishable from other anurans nearby (Hallock 1998). Once pools were created, surveys were conducted to count and document species with chorus surveys. Chorus surveys were performed by a minimum of two staff at locations near the edge of the pool where species, number of individuals and displacement from the surveyors could be determined. Surveys were performed during hours of darkness starting no sooner than civil twilight. Two chorus surveys were performed; one at the start of the breeding season and the other late in the breeding season. Arrival at the monitoring location was followed by a 5-minute "quiet" period to let anurans in the area adjust to the human presence. During a 10-minute monitoring session, species were identified from unique calls, and the number of calling individuals was estimated. Chorus surveys document the level of use in the pool, which was then correlated to the pool creation time and duration.

Field staff also set-up a trail camera at Pool 9 located at the 100-F Slough to monitor the fluctuations of the surface water level. This trail camera was set up to automatically take a picture at 30 minute intervals during daylight hours (Figure 2). 
HNF-56676

Revision 0

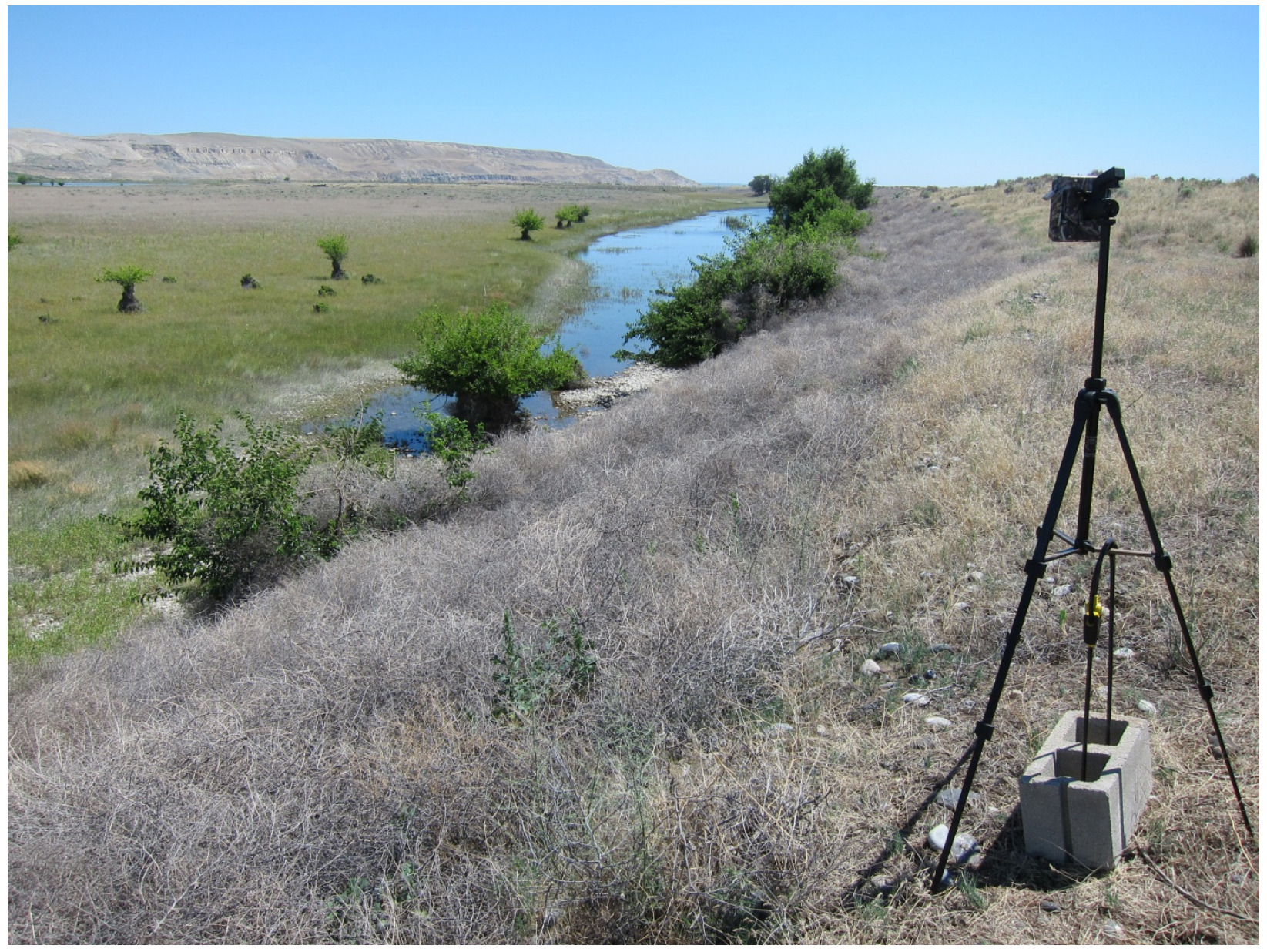

Figure 2. Field Camera Recording Surface Level Fluctuations at Pool 9 on the Hanford Site

Near the conclusion of the breeding season, tadpole collections were performed at two pools that had extended isolation periods. In a single pass around the edges of and through the pool, tadpoles were collected by small mesh nets as they were discovered. Using a tadpole identification key developed by the USGS Patuxent Wildlife Research Center (Altig et al 1998), the tadpoles collected were identified to species. 
HNF-56676

Revision 0

\subsection{Results}

Eight of the fifteen pools previously identified as suitable anuran breeding sites were surveyed during the 2013 monitoring season (Figure 3). Staff performed chorus surveys on the nights of May 2 and July 10, 2013. The two dates corresponded to an early breeding season and late breeding season survey. Because of the fluctuations in the river surface level, not all pools were isolated on those nights; however, all that were isolated were surveyed. Table 3 describes individuals recorded during those two nights.

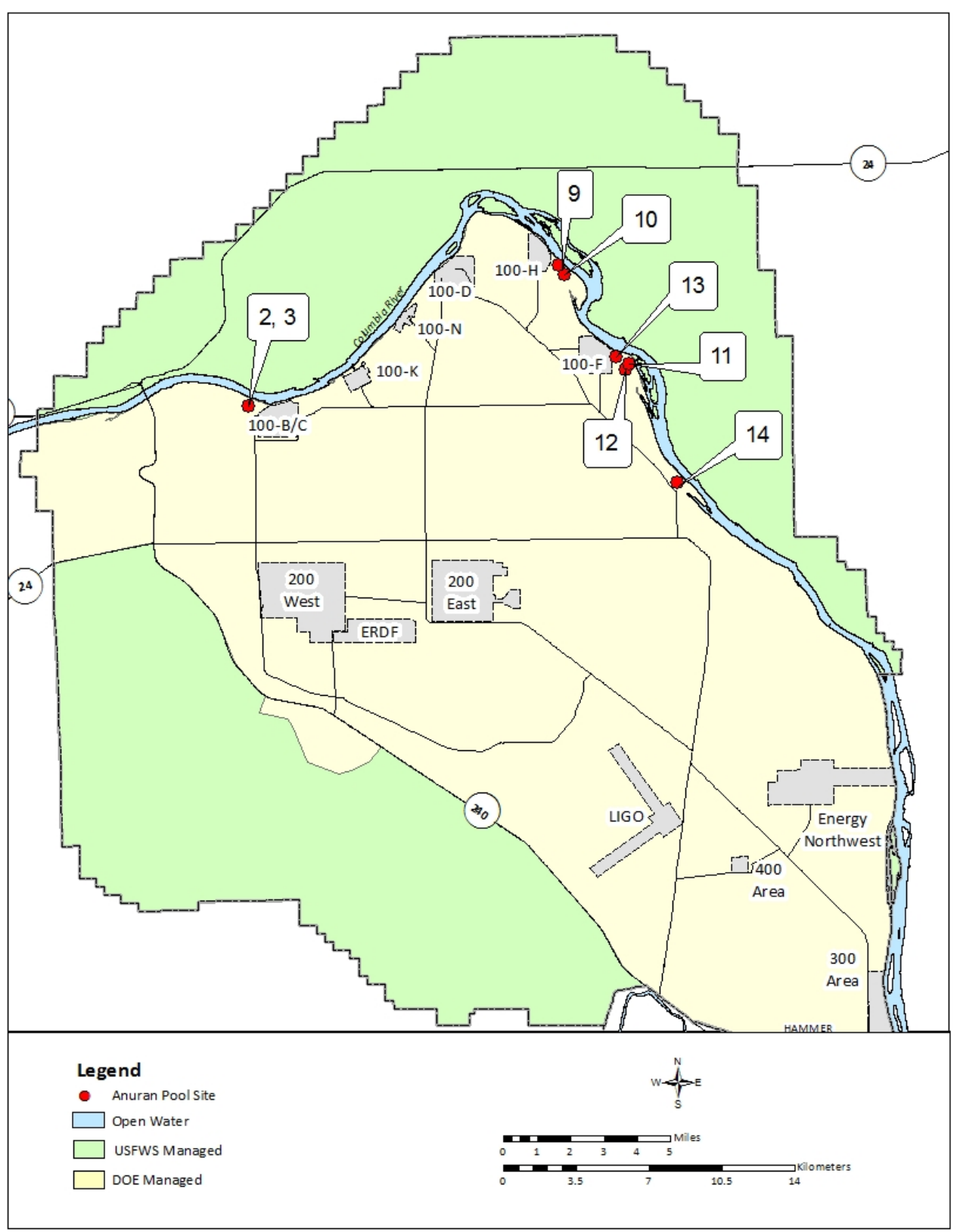

Figure 3. Anuran Pools Surveyed on the Hanford Site in 2013 
HNF-56676

Revision 0

Table 3. Individuals Documented by Species during Chorus Surveys, 2013

\begin{tabular}{|l|ccc|ccc|c|}
\multicolumn{9}{c}{$\mathbf{5 / 2 / 2 0 1 3}$} & $\mathbf{7 / 1 1 / 2 0 1 3}$ \\
\hline Location & ANWO $^{\mathbf{1}}$ & SPIN $^{\mathbf{2}}$ & LICA $^{3}$ & ANWO $^{\mathbf{1}}$ & SPIN $^{2}$ & LICA $^{3}$ & Totals \\
\hline Pool 2/3 & 10 & 7 & 0 & 0 & 0 & 4 & $\mathbf{2 1}$ \\
Pool 9 & 0 & 0 & 0 & 14 & 0 & 5 & $\mathbf{1 9}$ \\
Pool 10 & 0 & 0 & 0 & 6 & 0 & 4 & 10 \\
Pool 11 & 0 & 0 & 0 & - & - & - & 0 \\
Pool 12 & 0 & 0 & 0 & - & - & - & 0 \\
Pool 13 & 5 & 11 & 0 & 15 & 3 & 0 & $\mathbf{3 4}$ \\
Pool 14 & - & - & - & 2 & 0 & 10 & $\mathbf{1 2}$ \\
\hline Totals & $\mathbf{1 5}$ & $\mathbf{1 8}$ & $\mathbf{0}$ & $\mathbf{3 7}$ & $\mathbf{3}$ & $\mathbf{2 3}$ & $\mathbf{9 6}$ \\
\hline
\end{tabular}

${ }^{1}$ ANWO - A. woodhousii (Woodhouse's toad)

${ }^{2}$ SPIN - S. intermontana (Great Basin spadefoot toad)

${ }^{3}$ LICA - L. catesbeianus (American bullfrog)

Flow data was obtained from the U.S. Geological Survey (USGS) National Water Information System. Flow data is recorded every 15 minutes at the monitoring station. These data were used to calculate average flows on an hourly basis. Staff then used the filled and isolated trigger levels to determine when pools were created (Figure 4). Figure 4 shows flow data, including times when pools were created, through the middle of July when the two toad species typically stop calling or initiating any breeding cycles on the Hanford Site (Miller 2010). Table 4 displays the most recent isolations of all documented pools, which mostly occurred around the middle of July and later. Flows used in Table 4 were only documented through the end of August, after which no breeding initiation events would occur. With flows progressively dropping following the summer runoff and into the fall, any early-July breeding attempt would be unaffected by flow inundation. With the combination of warm spring/summer nights and the controlled flow of the Columbia River creating and isolating the 15 potential pool sites, the breeding season was considered from April - August. Only 4 pool sites other than pools $2 / 3$, which are landlocked, had any extended isolation period prior to the conclusion of breeding season. A map of pools with isolations that could have supported breeding prior to July 15 is shown in Figure 5. 
HNF-56676

Revision 0
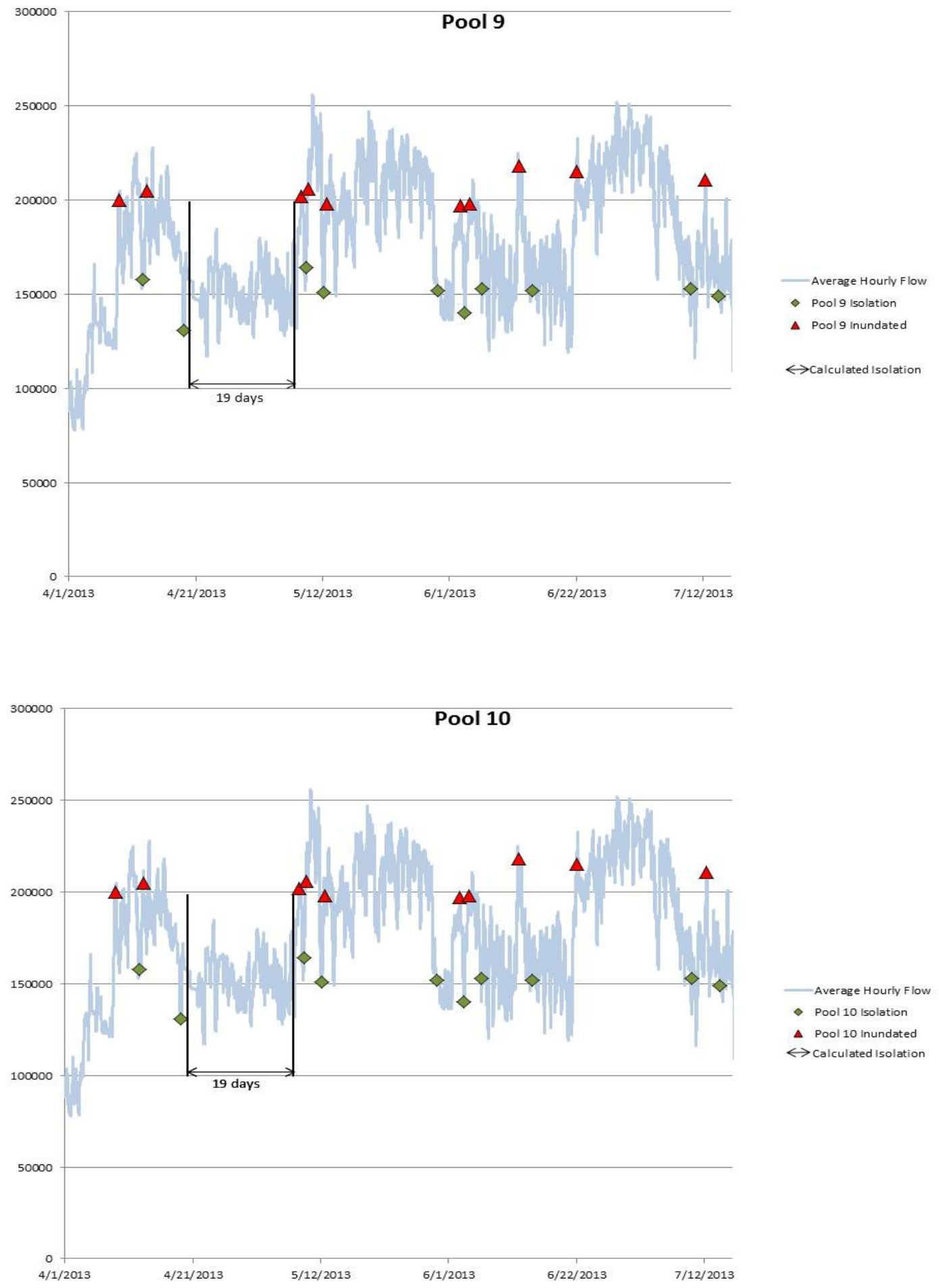

Figure 4. Average Hourly Flows and Isolation Periods of Four Riverine Pools for Potential Anuran Breeding 
HNF-56676

Revision 0
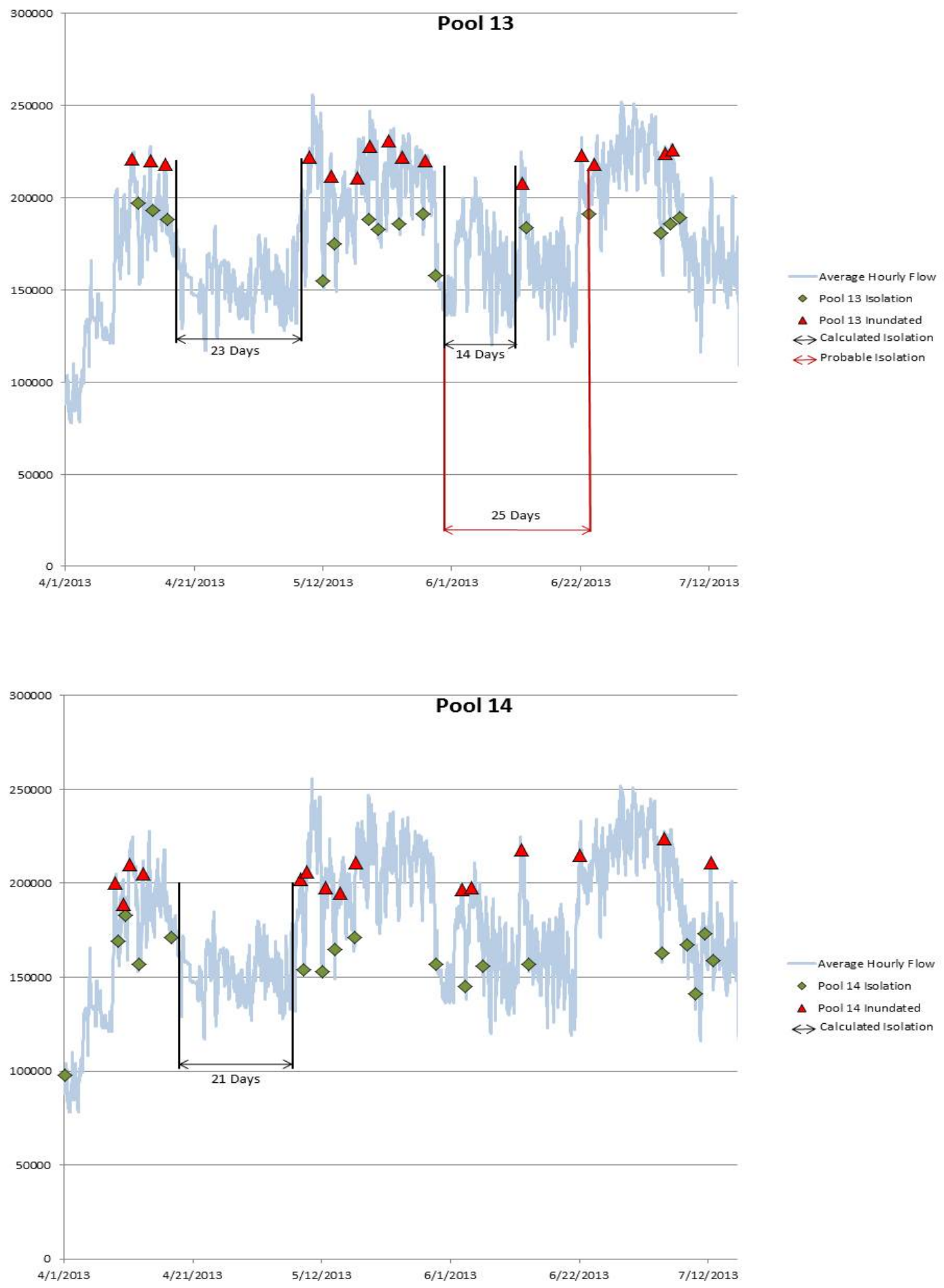

Figure 4 (continued). Average Hourly Flows and Isolation Periods of Four Riverine Pools for Potential Anuran Breeding 
Table 4. Pool Site Isolation Times on the Hanford Site during the Breeding Season

\begin{tabular}{lcc} 
Site Name & Most Recent Isolation Date & $\begin{array}{c}\text { Total Days of Most Recent Isolation } \\
\text { Through }\end{array}$ \\
\hline Pool 1 & August 31, 2013 \\
Pools 2/3 & N/A 2013 & 13 \\
Pool 4 & August 17, 2013 & Isolated year-round (Borrow pit) \\
Pool 5 & August 17, 2013 & 14 \\
Pool 6 & August 24, 2013 & 74 \\
Pool 7 & N/A & N/A \\
Pool 8 & N/A & N/A \\
Pool 9 & July 15, 2013 & 47 \\
Pool 10 & July 15, 2013 & 47 \\
Pool 11 & August 16, 2013 & 15 \\
Pool 12 & August 2, 2013 & 29 \\
Pool 13 & July 7, 2013 & 55 \\
Pool 14 & July 13, 2013 & 49 \\
Pool 15 & August 24, 2013 & 7
\end{tabular}


HNF-56676

Revision 0

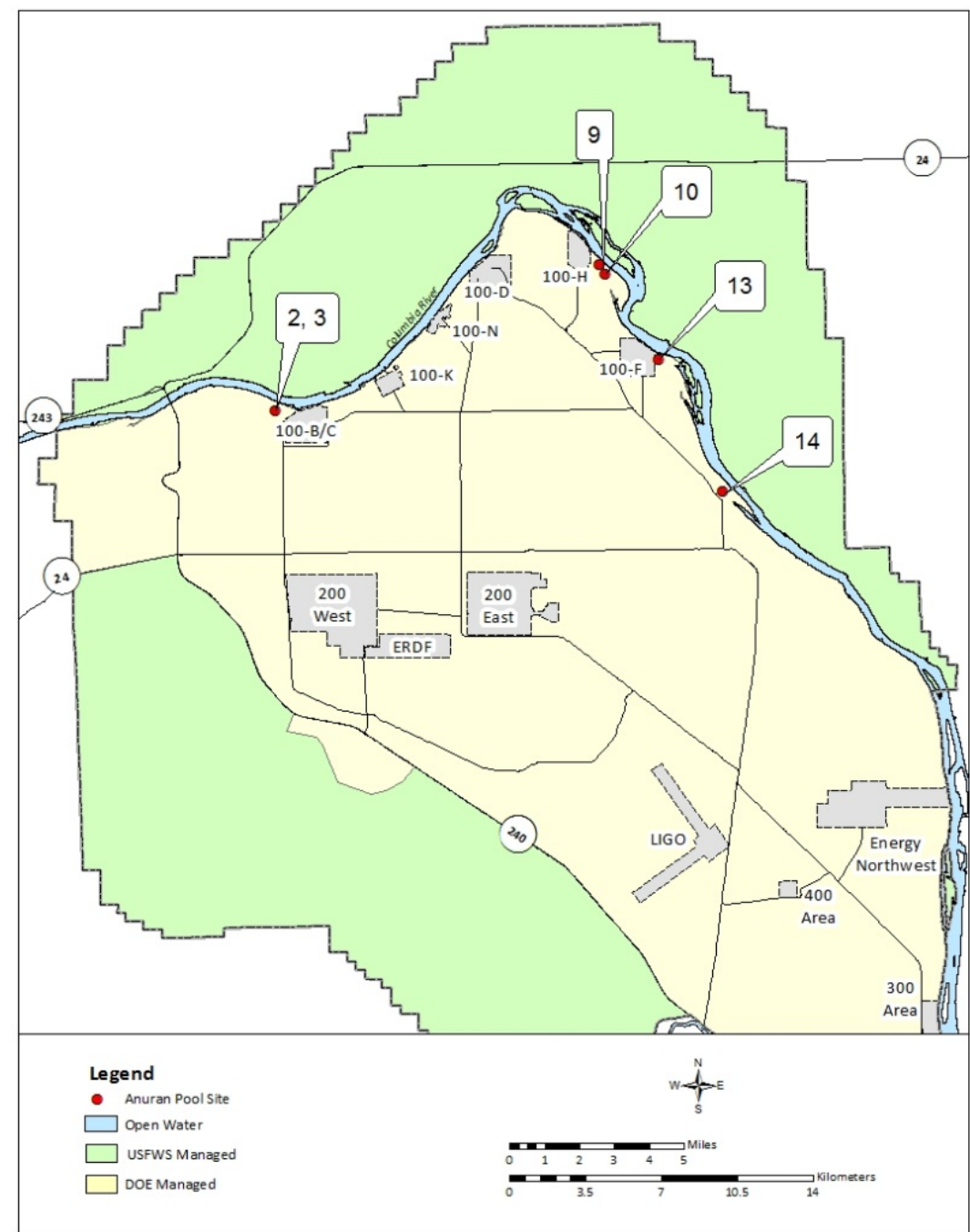

Figure 5. Anuran Breeding Pools on the Hanford Site with Sufficient Time for Breeding to Occur by End of August 2013

On July 25, 2013, staff went to Pools $2 / 3$ and Pool 13 in attempts to locate and catch tadpoles to confirm successful breeding. Using small mesh nets, project personnel collected 15 juvenile tadpoles and 9 metamorphosed Woodhouse's Toad from Pools $2 / 3$. Juvenile tadpoles from Pools $2 / 3$ were in varied stages of metamorphosis. Hind limbs and some budding forelimbs were common; tadpoles without any limb development were a rarity. A large number of completely metamorphosed Woodhouse's Toad were seen at the edge of the Pools s $2 / 3$ and multiple American bullfrogs were heard and seen jumping from the bank. A total of 14 Woodhouse's Toad juvenile tadpoles were netted at Pool 13. Tadpoles at this location were small and generally lacked limb development. A limited number possessed budding or grown hind limbs and no tadpoles had any sign of forelimb development. Pool 13 had a single American bullfrog seen on the waters' edge but no other adults or metamorphosed toads were seen. Classification of live tadpoles can be difficult in field settings without causing mortality to the individuals. 
However, by best available techniques, tadpoles of spadefoot toad or American bullfrog were not located at either pool.

The trail camera was placed to document the changes to the pool during flow variations. During the time the camera was active, the flows did not increase to an inundation level. The camera showed how the isolated pool slowly reduced in size over time.

\subsection{Discussion}

The 2013 monitoring season confirmed the three anuran species Woodhouse's Toad, spadefoot toad and American bullfrog that have been consistently recorded on the Hanford Site during previous monitoring efforts. Species that are potentially present such as the Western toad, the Northern leopard frog and the Pacific chorus frog were not documented during 2013. Chorus counts, using protocols as described in Miller 2010, were performed to document the species present and verify that breeding was occurring at pools after they were isolated. Table 3 provides information about the timing of anuran chorusing similar to that seen in 2006 and 2008 (Miller 2010). Spadefoot toad and Woodhouse's Toad begin chorus and breeding early in the season before American bullfrog. A late season chorus survey then showed higher American bullfrog breeding activity while spadefoot toad activity dropped drastically. From 2006 and 2008, chorusing anurans were observed at nine locations of the 15 identified pools.

All three species recorded in 2006 and 2008 were also documented in 2013. Although breeding habits are being influenced by river fluctuations, some successful reproduction appears to be occurring. However, no pools remained fully isolated between April and July for the duration required for complete larval development (47 days in spadefoot toad and approximately 56 days in Woodhouse's Toad (Lannoo 2005) (Figure 4). Flow levels during 2013 were above the ten year average. The flow levels from 2013 are compared to the ten year average, as well as a relatively high and relatively low flow year during the past ten years (NWIS) (Figure 6). 


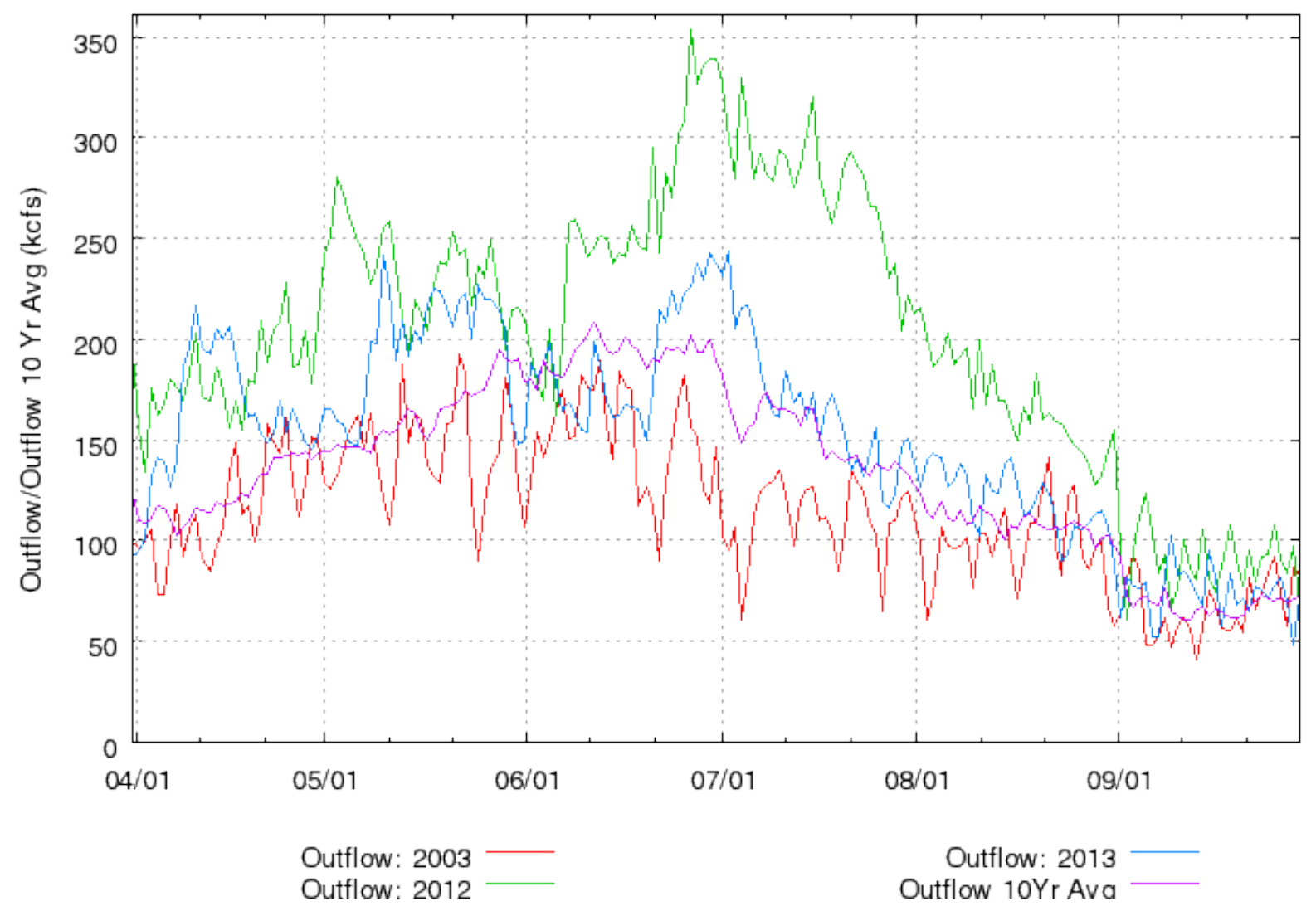

Figure 6. Outflow at Priest Rapids Dam During 2013 Compared to a High, Low, and 10 Year Average Outflow (CRDART 2013)

With the majority of pools located in sloughs or shorelines of the Columbia River, river flows have an impact on the availability of viable breeding habitat. In 2006, when Pool 13 was inundated and then isolated, native anurans were observed chorusing. However when the channel was filled again and connected to the main river channel, chorusing ceased (Miller 2010). When chorusing ceases, new breeding attempts are not being made by the native toads. This shows a direct relationship between discharge fluctuations from upriver dams and the breeding cycles of anurans on the Hanford Site. As mentioned previously, it is assumed that a level of reproduction success must be occurring at these pools for them to be reused year after year. When analyzing the tadpoles of Woodhouse's Toad in both Pools $2 / 3$ and Pool 13, it was immediately apparent that the Pool 13 tadpoles were much less developed compared to those in Pool $2 / 3$. Because Pools $2 / 3$ is away from the river, and only filled via groundwater infiltration, it does not undergo the filling and isolation patterns of the pools along the river shorelines. The isolated Pools $2 / 3$ anurans had tadpoles many stages of metamorphosis, ranging from tadpoles without any limb budding to fully metamorphosed offspring that had emerged from the pool. In Pool 13 however, all tadpoles were in a very similar stage of development. Tadpoles either had no limb budding or had begun producing only hind limbs. The tadpole sampling event on July 25, 2013 followed the early July isolations. Had Pool 13 been unaffected by the late June discharge increases (Figure 4), the tadpole development would likely have had shown more resemblance to the always 
isolated Pools $2 / 3$. Thus, it appears that river fluctuations may have delayed breeding and maturation of tadpoles at Pool 13. While flow fluctuations do not seem to entirely prevent anuran breeding along the shorelines of the Columbia River at the Hanford Site, the flow models, chorus surveys and tadpole development stages of a few pools show that anuran breeding schedules may be affected.

Many factors affect the creation, persistence, and suitability of anuran breeding pools along the Hanford Reach. Although pools along the shoreline are filled by high flows, and then isolated from the main river channel by receding flows, other factors such as how fast the river rises and drops, groundwater levels, soil permeability, evaporation rates, vegetation levels, pool depth, and water temperature also affect the breeding success. The overall level of water availability also influences pool creation; some pools may not be filled for an entire season during a low flow year, while others may never become isolated during a high flow year. When water levels rise, the relatively warm pools are inundated by cold river water, likely influencing the suitability for breeding and egg/larval development. Rising flows could also flush tadpoles or eggs into the main channel where they are exposed to predators. The fate of tadpoles and/or eggs that are washed into the main channel is not known.

It is apparent that the modified flow regime is impacting anuran breeding on the Hanford Reach, but the extent of the impact is unknown. Further analysis is needed to fully understand how chorus initiation and larval maturation is impacted by changing pool conditions. The presence of Hanford Site contaminants in breeding areas could also impact anuran species, which can be especially sensitive to environmental contaminants. Investigations into the presence and level of contaminants in these breeding and overwintering areas would help determine if any impacts to the populations could be occurring. These answers could help explain the stresses and challenges that native anurans face on the Hanford Reach and provide a clearer picture of the status and health of the populations. 
HNF-56676

Revision 0

\subsection{References}

Altig, Ronald., R. W. McDiarmid, K. A. Nichols, and P. C. Ustach, 1998, Tadpoles of the United States and Canada: A Tutorial and Key, United States Geological Survey, Patuxent Wildlife Research Center. Online at: http://www.pwrc.usgs.gov/tadpole/default.htm.

Anglin, D.R., S.L. Haeseker, J.J. Skalicky, H. Schaller, K.F Tiffan, J.R. Hatten, P. Hoffarth, J. Nugent, D. Benner, M. Yoshinaka. 2006. Effects of Hydropower Operations on Spawning Habitat, Rearing Habitat, and Stranding/Entrapment Mortality of Fall Chinook Salmon in the Hanford Reach of the Columbia River, Final Report, Columbia River Fisheries Program Office, U.S. Fish and Wildlife Service, Vancouver, Washington. Online at: http://www.fws.gov/columbiariver/publications/final hanford report 8-102006.pdf.

Becker, J. M. and B. F. Miller, 2005, "Amphibians" Section 8.11.1.5 in Hanford Site Environmental Report for Calendar Year 2004, Pacific Northwest National Laboratory, Richland, Washington. Online at: http://www.pnl.gov/main/publications/external/technical reports/pnnl-15222.pdf.

Becker, James, 2011, Amphibians, Pacific Northwest National Laboratory - Hanford National Environmental Research Park. Online at: http://nerp.pnnl.gov/projects f\&w/frogs.asp.

Burk, K. W., M. A. Chamness, R. A. Fowler, B. G. Fritz, P. L. Hendrickson, E. P. Kennedy, G. V. Last, T. M. Poston, M. R. Sackschewsky, M. J. Scott, S. F. Snyder, M. D. Sweeny, P. D. Thorne. and J. P. Duncan (editor), 2007, Hanford Site National Environmental Policy Act (NEPA) Characterization, Pacific Northwest National Laboratory. PNNL-6415 Rev. 18. Richland, Washington. Available online at: http://www.pnl.gov/main/publications/external/technical reports/pnnl-6415rev18.pdf.

Campbell, N.A. and J.B. Reece, 2002, Biology $-6^{\text {th }}$ ed., Benjamin Cummings, San Francisco, California.

Comprehensive Environmental Response, Compensation, and Liability Act of 1980, 42 U.S.C. 9601-9675. (P.L. 96-510).

CRDART (Columbia River Data Access in Real Time), Columbia Basin Research, University of Washington, 2013. Online at: http://www.cbr.washington.edu/dart/query/river graph text.

DOE/EIS-0222-F, 1999, Final Hanford Comprehensive Land-Use Plan Environmental Impact Statement, U.S. Department of Energy, Washington, D.C. Online at: http://energy.gov/nepa/downloads/eis-0222final-environmental-impact-statement-0.

Hallock, L., 1998, Herpetofauna of the Hanford Nuclear Reservation, Grant, Franklin and Benton Counties, Washington, Unpublished report submitted to The Nature Conservancy, Seattle, WA, 43pp.

Hayes, M. P., C. J. Rombough, G. E. Padgett-Flohr, L. A. Hallock, J. E. Johnson, R. S. Wagner, and J. D. Engler, 2009, Amphibian Chytridiomycosis in the Oregon Spotted Frog (Rana pretiosa) in Washington State, USA, Northwestern Naturalist, 90:148-151. Online at: http://wdfw.wa.gov/publications/00853/wdfw00853.pdf.

Lannoo, M., editor, 2005, Amphibian Declines: The Conservation Status of United States Species, University of California Press, Berkely, CA, 1094 pages. 
HNF-56676

Revision 0

McAllister, K.R., Leonard, W.P., D.W. Hays, and R. C. Friesz, 1999, Washington State Status Report for the Northern Leopard Frog, Wash. Dept. Fish and Wildlife, Olympia, 36 pp.

http://wdfw.wa.gov/publications/00378/wdfw00378.pdf.

Miller, B.A., 2004, Characterization of Anuran Breeding Sites on the Hanford Reach, Office of Science, Student Undergraduate Laboratory internship (SULI), Washington State University, Pacific Northwest National Laboratory, Richland, Washington.

Miller, B.A., 2010, Anuran Utilization of a Semi-Arid Regulated River Environment, The Hanford Reach of the Columbia River, Master's Thesis, Washington State University.

National Environmental Policy Act of 1969, 42 U.S.C. 4321, et seq. (P.L. 91-190).

United States Geological Survey (USGS). 2013. Nation Water Information System (NWIS), USGS 12472800 Columbia River Below Priest Rapids Dam, WA. Online at: http://waterdata.usgs.gov/usa/nwis/uv?site no=12472800.

TNC (The Nature Conservancy of Washington). 1999. Biodiversity Inventory and Analysis of the Hanford Site, Final Report 1994-1999, Seattle, WA. Online at: http://nerp.pnnl.gov/docs/ecology/biodiversity/biodiversity 1999.pdf.

WDFW (Washington Department of Fish and Wildlife). 2003. Assessment of Losses of Juvenile Fall Chinook in the Hanford Reach of the Columbia River in Relation to Flow Fluctuations, Field Summary report. Olympia, WA.

WDFW (Washington Department of Fish and Wildlife). 2013. Species of Concern, Online at: http://wdfw.wa.gov/conservation/endangered/. 